\title{
Loss of Ovarian Function Results in Increased Loss of Skeletal Muscle in Arthritic Rats
}

\section{Perda da função ovariana resulta em perda de músculo esquelético aumentada em ratos artríticos}

\author{
Roberto Furlanetto Júnior ${ }^{1}$ Fernanda Maria Martins ${ }^{1}$ Anselmo Alves de Oliveira ${ }^{1}$ \\ Paulo Ricardo Prado Nunes ${ }^{1}$ Márcia Antoniazi Michelin ${ }^{2}$ Eddie Fernando Candido Murta ${ }^{2}$ \\ Fábio Lera Orsatti ${ }^{1}$
}

${ }^{1}$ Exercise Biology Research Group (BioEx), Health Sciences Institute, Universidade Federal do Triângulo Mineiro (UFTM), Uberaba, Minas Gerais, Brazil

2 Research Institute of Oncology (IPON), Discipline of Gynecology and

Address for correspondence Fábio Lera Orsatti, PhD, UFTM, Exercise Biology Laboratory (BioEx). Av. Tutunas, 490, 38061-500-Uberaba, MG, Brazil (e-mail: fabiorsatti@gmail.com).

Obstetrics, UFTM, Uberaba, Minas Gerais, Brazil

Rev Bras Ginec Obst 2016;38:56-64.

\begin{abstract}
\section{Keywords}

- cachexia

- rheumatoid arthritis

- E3 ubiquitin ligase

- ovariectomy

- disuse

Objective We studied the effects of loss of ovarian function (ovariectomy) on muscle mass of gastrocnemius and the mRNA levels of IGF-1, atrogin-1, MuRF-1, and myostatin in an experimental model of rheumatoid arthritis in rats.

Methods We randomly allocated 24 female Wistar rats (9 weeks, $195.3 \pm 17.4$ grams) into four groups: control (CT-Sham; $n=6)$; rheumatoid arthritis $(R A ; n=6)$; ovariectomy without rheumatoid arthritis $(\mathrm{OV} ; \mathrm{n}=6)$; ovariectomy with rheumatoid arthritis (RAOV; $n=6$ ). We performed the ovariectomy (OV and RAOV) or Sham (CTSham or RA) procedures at the same time, fifteen days before the rheumatoid arthritis induction. The RA and RAOV groups were immunized and then were injected with MetBSA in the tibiotarsal joint. After 15 days of intra-articular injections the animals were euthanized. We evaluated the external manifestations of rheumatoid arthritis (perimeter joint) as well as animal weight, and food intake throughout the study. We also analyzed the cross-sectional areas (CSA) of gastrocnemius muscle fibers in 200 fibers (H\&E method). In the gastrocnemius muscle, we analyzed mRNA expression by quantitative real time PCR followed by the Livak method $(\triangle \Delta C T)$.

Results The rheumatoid arthritis induced reduction in CSA of gastrocnemius muscle fibers. The RAOV group showed a lower CSA of gastrocnemius muscle fibers compared to RA and CT-Sham groups. Skeletal muscle IGF-1 mRNA increased in arthritics and ovariectomized rats. The increased IGF-1 mRNA was higher in OV groups than in the RA and RAOV groups. Antrogin-1 mRNA also increased in the gastrocnemius muscle of arthritic and ovariectomized rats. However, the increased atrogin-1 mRNA was higher in RAOV groups than in the RA and OV groups. Gastrocnemius muscle MuRF-1 mRNA increased in the OV and RAOV groups, but not in the RA and Sham groups. However, the
\end{abstract}

received

November 19, 2015

accepted

December 1, 2015

published online

February 2, 2016
DOI http://dx.doi.org/

$10.1055 / \mathrm{s}-0035-1571265$. ISSN $0100-7203$
Copyright $\odot 2016$ by Thieme Publicações License terms Ltda, Rio de Janeiro, Brazil
$\Theta(1) \Theta$ 


\section{Resumo}

\author{
Palavras-chave \\ - caquexia \\ - artrite reumatoide \\ - E3 ubiquitina-ligase \\ - ovariectomia \\ - desuso
}

RAOV group showed higher MuRF-1 mRNA than the OV group. The myostatin gene expression was similar in all groups.

Conclusion Loss of ovarian function results in increased loss of skeletal musclerelated ubiquitin ligases atrogin-1 and MuRF-1 in arthritic rats.

Objetivo Foram estudados os efeitos da perda da função ovariana (ovariectomia) sobre músculo esquelético e os níveis de RNAm de IGF-1, atrogina-1, MuRF-1, e de miostatina em modelo experimental de artrite reumatóide em ratos.

Métodos 24 ratos Wistar (9 semanas, 195,3 \pm 17,4 gramas) foram distribuídos aleatoriamente em quatro grupos: controle (CT-Sham, $n=6$ ); artrite reumatóide (RA, $n=6$ ); ovariectomia sem artrite reumatóide (OV; $n=6$ ); ovariectomia com artrite reumatóide (RAOV; $n=6$ ). Os procedimentos da ovariectomia (OV e RAOV) ou simulação da ovariectomia (CT-Sham ou RA) foram realizados ao mesmo tempo, quinze dias antes da indução da artrite reumatóide. Os grupos RA e RAOV foram imunizados e, em seguida, foram injetados com Met-BSA na articulação tibiotársica. Após 15 dias das injeções intra-articulares, os animais foram eutanasiados. Foram avaliadas as manifestações externas da artrite reumatóide (perimetria articular), bem como o peso dos animais e a ingestão de alimentos ao longo do estudo. Além disso, as áreas de secção transversa (CSA) do músculo gastrocnêmio foram analisadas em 200 fibras (método H \& E). No músculo gastrocnêmio, a expressão de RNAm foi analisada por PCR quantitativo em tempo real, seguido pelo método Livak $(\triangle \triangle C T)$.

Resultados A artrite reumatoide reduziu a CSA das fibras do músculo gastrocnêmio. O grupo RAOV mostrou uma CSA menor nas fibras do músculo gastrocnêmio em comparação com os grupos RA e CT-Sham. O RNAm do IGF-1 do músculo esquelético aumentou nos ratos artríticos e ovariectomizados. O RNAm do IGF-1 foi maior nos grupos OV do que nos grupos RA e RAOV. A expressão de antrogina-1 também aumentou no músculo gastrocnêmio dos ratos artríticos e ovariectomizados. No entanto, o aumento do RNAm da atrogina-1 foi maior no grupo RAOV do que nos grupos RA e OV. O RNAm da MuRF-1 aumentou nos grupos OV e RAOV, mas não nos grupos RA e CT-Sham. Porém, o grupo RAOV apresentou maior expressão gênica de MuRF-1 do que o grupo OV. A expressão do gene da miostatina foi semelhante em todos os grupos.

Conclusão A perda de função ovariana resulta em perda de músculo esquelético associado às ubiquitina-ligases atrogina-1 e MuRF-1 em ratos artríticos.

\section{Introduction}

Loss of skeletal muscle (LSM) has been postulated to be an important contributor to increasing morbidity and mortality. ${ }^{1}$ LSM is a serious consequence of rheumatoid arthritis ${ }^{1}$ especially in women. ${ }^{2}$ The complex nature of rheumatoid arthritis-induced LSM is associated with chronic inflammation, insulin and insulin-like growth factor (IGF)-1 resistance, and reduced physical activity. ${ }^{3}$ While these disorders have been widely investigated, there are still gaps in our understanding of the regulatory role of loss of ovarian function (LOF) in the progression of LSM in rheumatoid arthritis. LOF has the potential to be a contributor to LSM directly, and also through interactions with inflammation. ${ }^{4}$ While previous studies have demonstrated the harmful potential role of LOF in LSM, they fall short in replicating the disrupted systemic environment created by rheumatoid arthritis. Since women naturally progress to menopause or may undergo ovariectomy, a better understanding of effects of LOF in LSM during rheumatoid arthritis and their regulatory pathways could identify new therapeutic targets.

Estrogen treatment reportedly enhances muscle mass recovery following atrophy or injury in rodents and helps retain muscle mass in postmenopausal women. ${ }^{4}$ As for the mechanisms in skeletal muscle that are influenced by estrogen, Dieli-Conwright et $\mathrm{al}^{5,6}$ have reported greater levels in expression of muscle mRNA of myostatin and E3 ubiquitin ligases (Atrogin-1/MAFbx and MuRF-1) in postmenopausal women relative to postmenopausal women taking hormone replacement. Moreover, myostatin is a member of the transforming growth factor (TGF)- $\beta$ family that negatively regulates skeletal muscle growth by inhibition of satellite cell 
activation. ${ }^{7}$ Myostatin has been associated with activation of E3 ubiquitin ligases genes in skeletal muscle. ${ }^{8}$ E3 ubiquitin ligases cause proteins to be degraded by the $26 \mathrm{~S}$ proteasome and it has been reported to induce skeletal muscle atrophy. ${ }^{9}$ These results highlight the beneficial role of estrogen on skeletal muscle, suggesting that the LOF may induce increase of myostatin, atrogin- 1 and MuRF-1, causing muscle atrophy. In this context, it would seem reasonable to assume that the LOF is extremely harmful to skeletal muscle in rheumatoid arthritis since rheumatoid arthritis has been consistently reported to upregulate atrogin-1 and MuRF-1 in skeletal muscle atrophy.

LSM in rheumatoid arthritis has also been associated with increase in muscle IGF-1 gene expression. ${ }^{10-12}$ Given that the IGF-1 is an important stimulator of skeletal muscle growth, upregulation of IGF-1 during the rheumatoid arthritis could be an attempt to mitigate muscle atrophy. ${ }^{13,14}$ The literature reports an established link between estrogen and upregulation of IGF-1-signalling-related muscle mass maintenance in LOF. Estrogen receptor agonists treatment in ovariectomized rodents $^{15}$ and estrogen replacement in postmenopausal women $^{16}$ reportedly upregulate IGF-1-signalling-related muscle mass hypertrophy and maintenance, respectively. However, while these studies suggest that LOF seems to be associated with downregulation of IGF-1-signalling-related muscle mass maintenance, ovariectomy in rats can augment muscle IGF-1 mRNA expression and muscle hypertrophy and these changes were reversed by estrogen replacement. ${ }^{17}$ In addition, a recent study reported that estrogen supplementation decreases muscle levels of IGF-1 in ovariectomized rats. $^{18}$ Therefore, the LOF linked muscle atrophy via decreased IGF-1 remains unclear.

Although researchers widely mention the LOF as having great potential for promoting a catabolic molecular milieu in skeletal muscle, they have not yet established its role during the progression of rheumatoid arthritis. Thus, to tackle this problem, we studied the effects of ovariectomy on muscle mass of gastrocnemius and the mRNA levels of IGF-1, atrogin-1, MuRF-1, and myostatin in an experimental model of rheumatoid arthritis (adjuvant-induced arthritis) in rats. This paper clarifies the molecular responses of the skeletal muscle to LOF during rheumatoid arthritis.

\section{Methods}

This experimental study was in accordance with the National Guide for Care and use of Laboratory Animals (Conselho Nacional de Controle de Experimentação Animal (CONCEA)) and obtained the approval of the University Ethics Committee (No. 275/2014). All procedures were performed in Research Institute of Oncology (IPON) of the Universidade Federal do Triângulo Mineiro (UFTM).

We used female Wistar rats (195.3 \pm 17.4 grams) with nine weeks of age in present study. The rats were housed in plastic cages in standard conditions at $22^{\circ}, 12$-hour lightdark cycle, and had free access (ad libitum) to water and standard food (Nuvilab-CR1, Curitiba, PR, Brazil). Four experimental groups were used in this study: control
(CT-Sham; $\mathrm{n}=6$ ); group with rheumatoid arthritis (RA; $\mathrm{n}=6$ ); ovariectomy without rheumatoid arthritis (OV; $\mathrm{n}=6$ ); ovariectomy with rheumatoid arthritis (RAOV; $\mathrm{n}=6$ ). All rats received similar treatment in terms of daily manipulation. We performed the ovariectomy (OV and RAOV) or Sham (CT-Sham or RA) procedures at the same time, fifteen days before the rheumatoid arthritis induction. RA and RAOV groups were immunized and then the groups were injected with bovine albumin methylated (Met-BSA) in the tibiotarsal joint. Fifteen days after intra-articular injection, all animals were euthanized at the same period and day time. The gastrocnemius muscle samples of the left hind paw were removed, weighed, cleaned, and their white portion was obtained and stored in TRIzol at $80^{\circ} \mathrm{C}$ for molecular analysis. We investigated the gastrocnemius white portion because it possesses more fast-twitch fibers.

The rats were anesthetized with intraperitoneal injection solution containing ketamine $(80 \mathrm{mg} / \mathrm{kg})$ and Xylazine (10 $\mathrm{mg} / \mathrm{kg}$ ) for ovariectomy procedures. Ovariectomy was preceded by a single ventral transverse incision of $0.4-0.6 \mathrm{~cm}$ at the middle abdominal region according to the method described by Khajuria et al. ${ }^{19}$

We anesthetized the rats with intraperitoneal injection solution containing ketamine $(40 \mathrm{mg} / \mathrm{kg}$ ) and xylazine ( $5 \mathrm{mg} /$ $\mathrm{kg}$ ) for rheumatoid arthritis procedures. Initially, were immunized rats with two subcutaneous injections of $50 \mu \mathrm{L}$. MetBSA $(40 \mathrm{mg} / \mathrm{mL})$ diluted in glucose $5 \%$ emulsified with Freund's Complete Adjuvant (FCA) (supplemented with 1 $\mathrm{mg} / \mathrm{ml}$ of inactivated Mycobacterium tuberculosis) into the base tail, with an interval of seven days between the injections. After seven days from last injection at base tail, an intra-articular injection of $25 \mu \mathrm{L}$ Met-BSA, FCA and glucose $5 \%$ was applied in the tibiotarsal joints. ${ }^{20}$

We examined joint edema, body weight, and food intake weekly after the second subcutaneous injection. We evaluated arthritis severity by measuring the joint edema of each animal. We assessed joint edema by size of latero-lateral thickness of the tarsal joint with analogic calipers (Starfer, São Paulo, SP, Brazil). ${ }^{21}$ We performed the joint edema with mean values (average arithmetic) of two hind paws.

We anesthetized animals with intraperitoneal injection solution containing Ketamine $(80 \mathrm{mg} / \mathrm{kg}$ ) and Xylazine (10 $\mathrm{mg} / \mathrm{kg}$ ). We performed euthanasia by cardiac puncture and hypovolemic shock.

We collected the blood samples by cardiac puncture in a vacuum-sealed system (Vacutainer, England) into a dry tube with gel separator. The sample was centrifuged for 10 minutes $(3.000 \mathrm{rpm})$ and samples were separated and stocked $(-20 C)$ for future analyses. The serum estradiol (MyBiosource, San Diego, CA, U.S.A.) was analyzed by enzymatic immunoassay ELISA. All assays were in accordance with the manufacturer's protocol.

We extracted muscle samples (50-70mg) from gastrocnemius white portion. We performed total RNA extraction using TRIzol (SIGMA-ALDRICH, Sto Louis MO, USA), following the manufacturer's protocol. After extraction, we resuspended a dry pellet in RNase-free water, treated with DNase I (Life Technologies, Carlsbad, CA, U.S.A.) to remove any 
possible DNA presence in sample. We quantified total RNA using a high precision fluorometer QUBIT 2.0 (Life Technologies, Carlsbad, CA, U.S.A.) and kit RNA BR Assay (Life Technologies, Carlsbad, CA, U.S.A.). All samples had RNA concentrations between $20-100 \mathrm{ng} / \mu \mathrm{L}$. When we found higher RNA values, we diluted samples in RNase-free water.

We quantified mRNA by the 7900HT Fast Real-Time PCR System (Life Technologies, Carlsbad, CA, USA) using Quantifast SYBR Green RT-PCR one-step kits (QIAGEN, Hilden, Germany). Thus, $1 \mu$ l RNA samples treated with DNAse

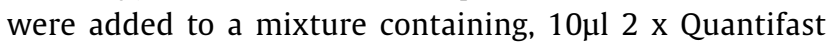
SYBR GREEN RT-PCR Master Mix, 0.2 $\mu$ l Quant Fast, 0.6 $\mu$ l primer sense and anti-sense and completed with RNAse Free water to reach the volume of $20 \mu$ l. We used annealing temperature and curve as measures of quality. The qPCR reaction conditions and cycles performed in the apparatus 7900HT Fast Real-Time PCR System (Life Technologies, Carlsbad, CA, USA) were as follows: $50^{\circ} \mathrm{C}$ per $10 \mathrm{~min}, 95^{\circ} \mathrm{C}$ per $5 \mathrm{~min}$ for initial denaturation, and amplification of 40 cycles $\left(95^{\circ} \mathrm{C}\right.$ per 10 seconds for denaturation, $60^{\circ} \mathrm{C}$ per 30 seconds for annealing and extension). We obtained fluorescence values between annealing/extension stages and determined threshold cycle numbers (CT) using SDS Software version 1.2.3 (Applied Biosystems, U.S.A.). mRNA IGF-1, MuRF-1, atrogin-1, and myostatin were normalized for GAPDH values (reference gene) and calculated by the Livak method $\left(\Delta \Delta \mathrm{C}_{\mathrm{T}}\right.$ ). Primers for all genes ( $\boldsymbol{- T a b l e ~} \mathbf{1}$ ) were obtained from previous studies ${ }^{10,22}$ and constructed from sequences published in GenBank (www.pubmed.com) to ensure the specificity of target sequences, as well as to avoid generation of secondary structures of primers and dimerization in each primer and between primers sense and antisense.

We performed morphological analyses from gastrocnemius histological sections ( $6 \mu \mathrm{m}$ thickness). The gastrocnemius histological sections were obtained in a microtome (Leica Biosystems, Nussloch, Germany) and stained with the hematoxylin and eosin (HE) method. We used the stained sections for photographic documentation of six random histological fields (20 x lens) (Nikon Evolucion MP 5.0). We used an image analysis software (Image J 1.46r) to determine the cross-sectional area (CSA) of 200 fibers per muscle.

\section{Statistical Analysis}

We tested the data for normal distribution using the Shapiro-Wilk test and for variance homogeneity using the Levene test. We compared the variables inter-groups by Kruskal-Wallis (nonparametric data). When appropriate ( $p<0.05$ ), we made a post hoc comparison test of subgroups. Data are expressed as median $\pm 25^{\text {th }}-75^{\text {th }}$ percentiles. We performed statistical procedures with a statistical software. Significance was set at $\mathrm{p}<0.05$.

\section{Results}

We measured circulating estradiol at the end of the study, after euthanasia (i.e. day 15 after intra-articular injection) to ensure the ovariectomy. The ovariectomized rats displayed decreased estradiol. In addition, the RA group also displayed decreased estradiol compared to the control group (-Table 1).

At beginning of the study (i.e., before of ovariectomy) the body weight did not differ between groups. However, in middle of the study (i.e., after ovariectomy and before intraarticular injection) the weight of ovariectomized rats increased compared with CT-Sham, while the weight of the RA group did not ( $\mathbf{- T a b l e ~} \mathbf{2}$ ).

Joint thickness, food intake, and body weight change were measured throughout the progression of rheumatoid arthritis. The thickness joint of arthritic rats (RA and RAOV) strongly increased seven days after intra-articular Met-BSA injection compared to CT-Sham and OV groups ( $\mathrm{Ht}=19.9$; $\mathrm{p}<0.01$ ). This increase in joint thickness was maintained up to the end study (at day 15). Although the ovariectomy did not affect the magnitude of joint thickness, the RAOV group showed higher joint thickness values than the RA group 15 days after intra-articular injection $(\mathrm{Ht}=20.9$; $\mathrm{p}<0.01)$ (-Fig. 1A). Food intake change was similar in RA and CTSham groups on day seven $(\mathrm{Ht}=14.5 ; \mathrm{p}<0.01)$. There was an increase in food intake for OV and reduction for RAOV

Table 1 Primers for qPCR

\begin{tabular}{|l|l|l|}
\hline Genes & Number (GenBank) & Sequence $\mathbf{( 5}^{\prime}$-3 $^{\prime}$ ) \\
\hline IGF-1 & NM_178866 & S: GCTATGGCTCCAGCATDCG \\
\cline { 3 - 3 } & & A: TCCGGAAGCAACACTCATCC \\
\hline MuRF-1 & NM_080903.1 & S: TGACCAAGGAAAACAGCCAC CAG \\
\cline { 3 - 3 } & & A: TCACT CCTTCTTCTCGTCCAGGATGG \\
\hline Atrogin & NM_133521.1 & S: TACTAAGGAGCGCCATGGATACT \\
\cline { 2 - 3 } & & A: GTTGAATCTTCTGGAATCCAGGAT \\
\hline Myostatin & NM_019151.1 & S: CTACCACGGAAACAATCATTACCA \\
\cline { 2 - 3 } & & A: AGCAAC ATTTGGGCTTTCCAT \\
\hline GAPDH & NM_001034034 & S: AGATGGTGAAGGTCGGAGTG \\
\cline { 3 - 3 } & & A: GAAGGTCAATGAAGGGGTCA \\
\hline
\end{tabular}


Table 2 Estradiol concentration, body weight, gastrocnemius weight in control (CT + Sham), ovariectomized rats (OV) and arthritic rats (RA) and arthritic rats with ovariectomy (RAOV)

\begin{tabular}{|c|c|c|c|c|c|}
\hline & CT-Sham & OV & RA & RAOV & $P$ \\
\hline Estradiol (pg.mL $\left.\mathrm{mL}^{-1}\right)$ & $\begin{array}{l}53.5 \\
(42.6-67.3)\end{array}$ & $\begin{array}{l}20.4^{*} \\
(16.8-23.3)\end{array}$ & $\begin{array}{l}31.8^{*} \\
(26.6-41.8)\end{array}$ & $\begin{array}{l}35.8^{*} \\
(31.3-38.4)\end{array}$ & 0.003 \\
\hline $\begin{array}{l}\text { Body weight before of } \\
\text { ovariectomy }(\mathrm{g})\end{array}$ & $\begin{array}{l}185.0 \\
(172.0-208.0)\end{array}$ & $\begin{array}{l}204.5 \\
(192.0-220.0)\end{array}$ & $\begin{array}{l}190.0 \\
(179.0-210.0)\end{array}$ & $\begin{array}{l}198.5 \\
(196.0-220.0)\end{array}$ & 0.227 \\
\hline $\begin{array}{l}\text { Body weight before of } \\
\text { intra-articular injection }(\mathrm{g})\end{array}$ & $\begin{array}{l}221.5 \\
(217.0-242.0)\end{array}$ & $\begin{array}{l}269.0^{*} \\
(251.0-286.0)\end{array}$ & $\begin{array}{l}237.0 \\
(230.0-256.0)\end{array}$ & $\begin{array}{l}271.0^{*} \\
(264.0-284.0)\end{array}$ & 0.012 \\
\hline Gastrocnemius weight $(\mathrm{g})$ & $\begin{array}{l}1.45 \\
(1.33-1.55)\end{array}$ & $\begin{array}{l}1.71 * \\
(1.61-1.86)\end{array}$ & $\begin{array}{l}1.10^{*} \\
(0.93-1.28)\end{array}$ & $\begin{array}{l}1.21 \\
(0.96-1.42)\end{array}$ & 0.002 \\
\hline $\begin{array}{l}\text { Gastrocnemius weight }(\mathrm{g}) \text {. } \\
\text { body weight }(\mathrm{g})^{-1} .100\end{array}$ & $\begin{array}{l}0.56 \\
(0.53-0.64)\end{array}$ & $\begin{array}{l}0.60 \\
(0.56-0.64)\end{array}$ & $\begin{array}{l}0.49 \\
(0.45-0.55)\end{array}$ & $\begin{array}{l}0.44^{*} \\
(0.40-0.50)\end{array}$ & 0.013 \\
\hline
\end{tabular}

Abbreviations: OV, ovariectomized rats; RA, arthritic rats; RAOV, arthritic rats with ovariectomy. Note: $\mathrm{n}=6$ rats per group. Data are expressed as median and $25-75$ percentiles.
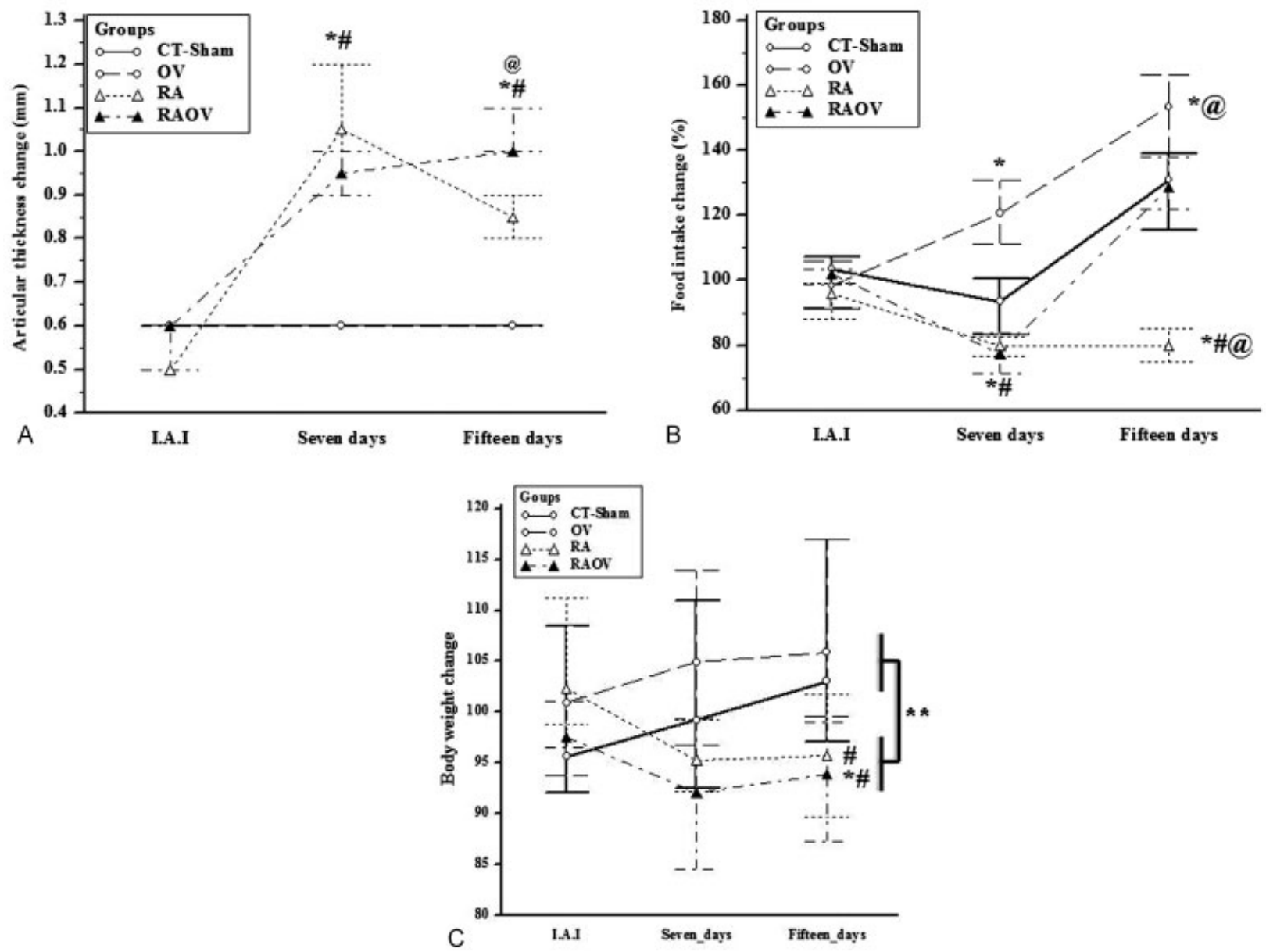

Fig. 1 (A) Joint thickness, (B) Food intake change (\%) and (C) Body weight change (\%) in control (CT + Sham), ovariectomized rats (OV) and arthritic rats (RA) and arthritic rats with ovariectomy (RAOV) at immediataly before intra-articular injection (I.A.I), seven days after intra-articular injection (seven days) and fifteen days after intra-articular injection (fifteen days). $n=6$ rats per group. Data are expressed as median and $25-75$ percentiles. ${ }^{*} p<0.05$ versus CT-Sham, ${ }^{* *} p<0,05$ vs pooled RA groups, $\# p<0.05$ versus OV and @ $p<0.05$ versus RA. 

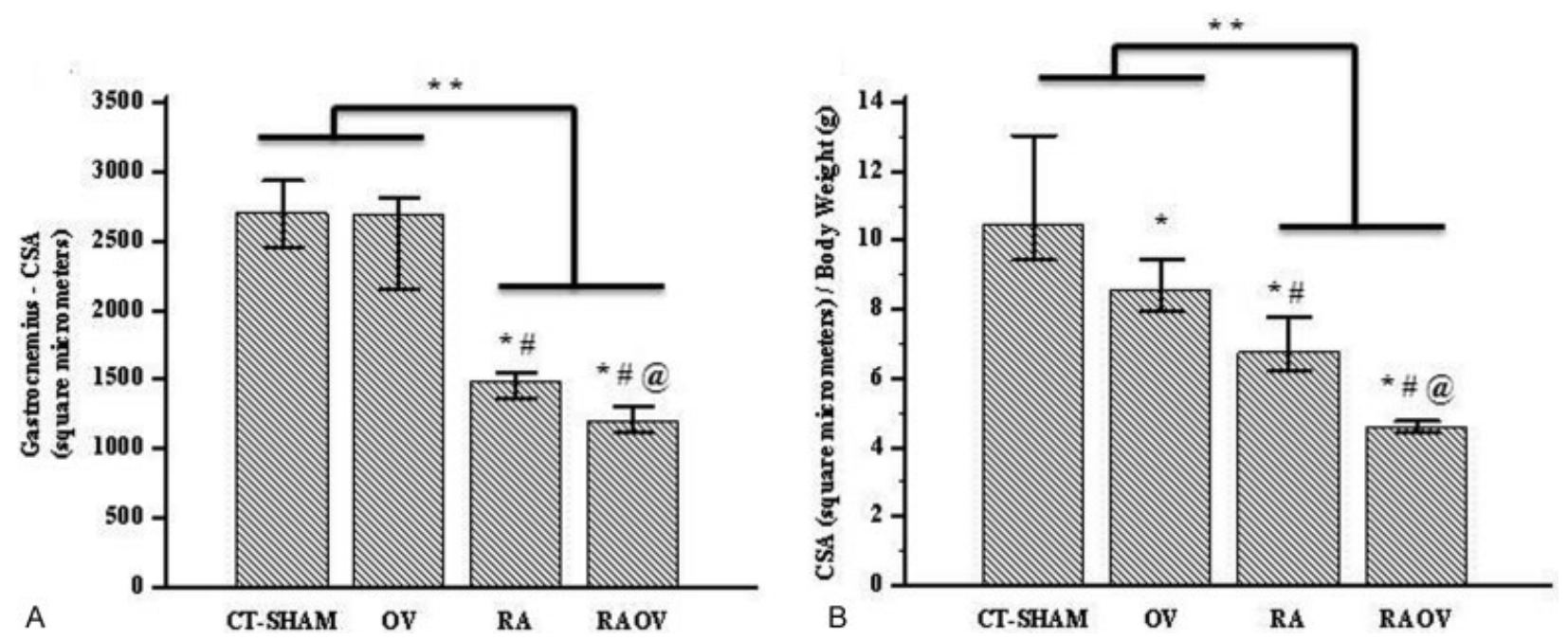

Fig. 2 (A) Cross sectional area (CSA) of gastrocnemius muscle fiber and (B) CSA correted by body weight in control (CT + Sham), ovariectomized rats $(\mathrm{OV})$ and arthritic rats (RA) and arthritic rats with ovariectomy (RAOV). $n=6$ rats per group. Data are expressed as median and $25-75$ percentiles ${ }^{*} p<0.05$ versus CT-Sham, \#p $<0.05$ versus OV and @ $p<0.05$ versus RA. ${ }^{* *} p<0,05$ vs pooled RA groups.

compared to CT-Sham. On day 15 , there was reduction in food intake for RA group compared to CT-Sham, OV and RAOV $(\mathrm{Ht}=16.5 ; \mathrm{p}<0.01)$. The OV food intake change was similar to CT-Sham group and the food intake gain was maintained in OV group (-Fig. 1B). Regarding body weight change, rheumatoid arthritis induced reduction in body weight related to control groups (CT-Sham $+\mathrm{OV})(\mathrm{p}<0.01)$. When the rats were divided in their specific conditions, there was no difference between groups on day seven $(\mathrm{Ht}=8.2$; $\mathrm{p}<0.01$ ). However, the RAOV group showed a lower body weight compared with control group on day 15 . Moreover, the RA group showed a lower body weight compared with OV group (-Fig. 1C).

To determine the muscle atrophy, we evaluated crosssectional area (CSA) of gastrocnemius muscle fibers (absolute) and CSA of gastrocnemius muscle fibers corrected by body weight (relative) in all groups. When we pooled the groups (RA + RAOV vs. CT-Sham $+\mathrm{OV}$ ), the group with rheumatoid arthritis induced reduction in absolute $(\mathrm{p}<0.01)$ and relative $(\mathrm{p}<0.01)$ CSA of gastrocnemius muscle fibers (-Fig. 2). When we separated the groups, the ovariectomized arthritic rats (RAOV) showed a lower absolute $(\mathrm{Ht}=18.7 ; \mathrm{p}<0.01)$ and relative $(\mathrm{Ht}=18.9$; $\mathrm{p}<0.01)$ CSA of gastrocnemius muscle fibers compared to arthritic rats without ovariectomy (RA). The OV showed a lower relative CSA of gastrocnemius muscle fibers compared to CT-Sham (- Fig. 2).

Skeletal muscle IGF-1 mRNA increased in arthritic and ovariectomized rats $(\mathrm{Ht}=14.6 ; \mathrm{p}<0.01)$. The increased IGF-1 mRNA was higher in OV groups than RA and RAOV groups ( - Fig. 3A). Antrogin-1 gene expression also increased in gastrocnemius muscle of arthritic and ovariectomized rats $(\mathrm{Ht}=15.9 ; \mathrm{p}<0.01)$. However, the increased atrogin-1 mRNA was higher in RAOV groups than RA and OV groups (-Fig. 3D). Gastrocnemius muscle MuRF-1 mRNA increased in ovariectomized, but not in arthritic rats $(\mathrm{Ht}=15.9$; $\mathrm{p}<0.01$ ). However, the RAOV group showed MuRF-1
mRNA values higher than the OV group ( $\mathbf{- F i g . ~} \mathbf{3 C}$ ). The myostatin gene expression was similar in all groups $(\mathrm{Ht}=1.9 ; \mathrm{p}=0.5)($-Fig. 3B $)$.

\section{Discussion}

The rheumatoid arthritis-induced LSM have been associated with chronic inflammation, insulin, and insulin-like growth factor (IGF)-1 resistance and reduced physical activity. ${ }^{3}$ While these disorders have been widely investigated, there are still gaps in our understanding of the regulatory role of LOF in the progression of LSM in rheumatoid arthritis. As women naturally (postmenopause) or surgically (ovariectomy) progress to LOF, understanding the role of LOF in the LSM during rheumatoid arthritis and their regulatory pathways could identify new therapeutic targets. Hence, in this study, we tested the effects of ovariectomy on muscle mass of gastrocnemius and genes expression of IGF-1, atrogin-1, MuRF-1, and myostatin in an experimental model of rheumatoid arthritis (adjuvant-induced arthritis) in rats. In the current study, the estradiol concentration and external signs of the illness measured by joint thickness showed success in ovarectomy and Met-BSA-induced arthritis (-Figs. 1 and 2). We found that the rheumatoid arthritis results in LSM and that LOF maximizes the LSM. We also showed that this increased LSM is associated with an increased E3 ubiquitin ligase gene expression in skeletal muscle (atrogin- 1 and MuRF-1).

In the current study, arthritic rats (RA + RAOV) showed reduction in body weight and CSA of gastrocnemius muscle fibers when compared with rats without arthritis (CT-Sham $+\mathrm{OV}$ ). Rheumatoid arthritis-induced muscle reduction has been consistently demonstrated in animal ${ }^{10,12,21}$ and human studies. ${ }^{3}$ Since arthritis decreases food intake, the decrease in skeletal muscle could be secondary to the decreased food intake. However, in arthritic rats with ovariectomy, which showed lower CSA of muscle fiber and CSA corrected by body 

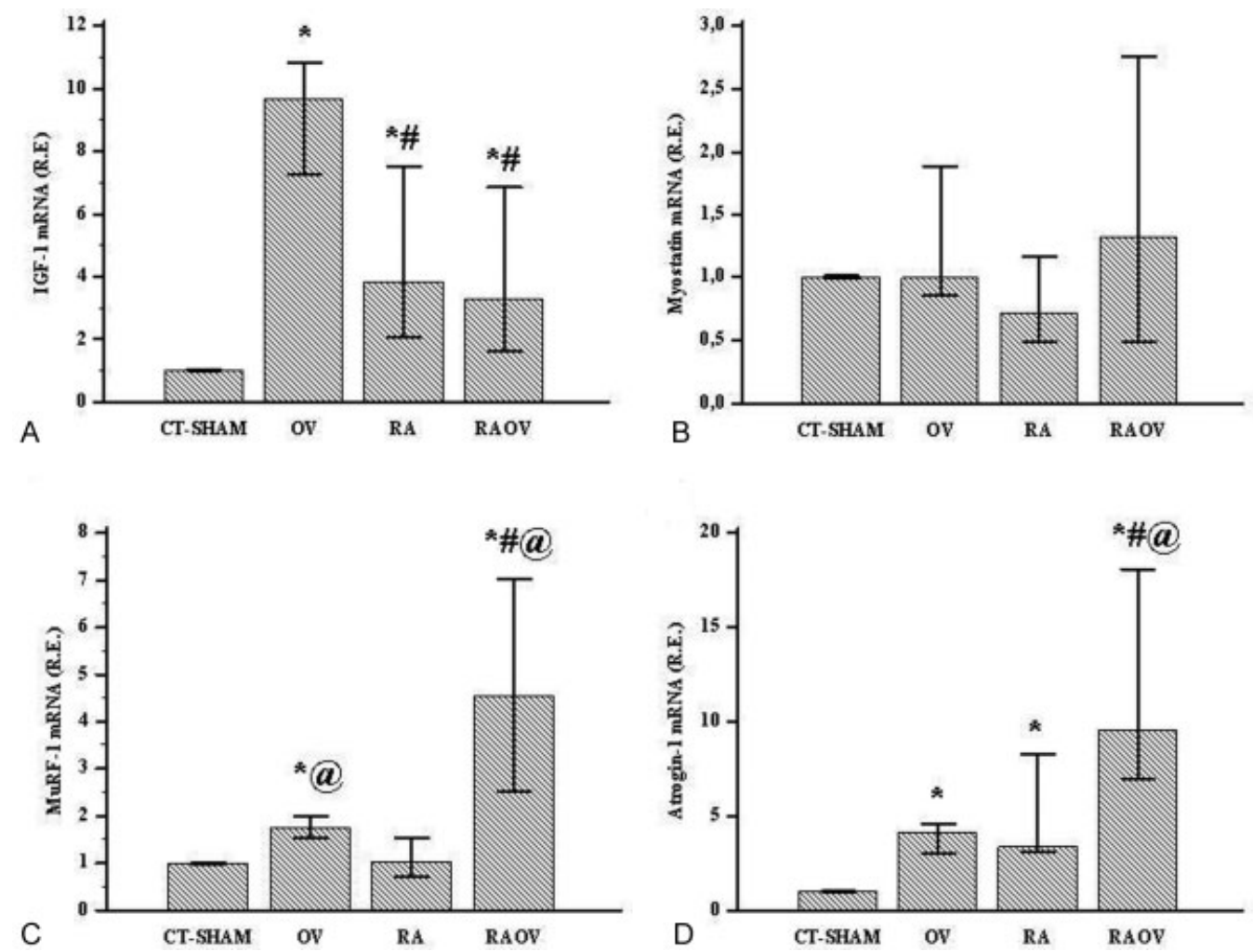

Fig. 3 IGF-1 mRNA (A), myostatin mRNA (B), MuRF-1 mRNA (C) and atrogin-1 mRNA in control (CT and Ex) and arthritics (RA and RAEx) rats in control (CT + Sham), ovariectomized rats (OV) and arthritic rats (RA) and arthritic rats with ovariectomy (RAOV). $n=6$ rats per group. Data are expressed as median and $25-75$ percentiles ${ }^{*} p<0.05$ versus CT-Sham, $\# p<0.05$ versus OV and @ $p<0.05$ versus RA. ${ }^{* *} p<0,05$ vs pooled RA groups.

weight, the food intake increased after day seven, reaching a food intake similar to the control in the last week of the study. Indeed, previous studies have shown that ovariectomy induces hyperphagia in rodents. ${ }^{23,24}$ But while ovariectomy can regain the food intake of rats with rheumatoid arthritis, this was not enough to regain the skeletal muscle in this study. Thus, rheumatoid arthritis-induced LSM cannot be attributed to the decrease in food intake. These findings are similar to those described by other researchers. ${ }^{10,12}$

We observed a strong increase in muscle IGF-1 mRNA in the OV group (-Fig. 3). Our findings converge with other researchers' previous findings, which have reported increase in muscle IGF-1 RNAm in ovariectomized immature rodents compared to estrogen replacement ones. ${ }^{17,18}$ In contrast to our findings, studies show that postmenopausal women have a reduction in muscle gene expression of IGF-1 compared to premenopausal women. ${ }^{16}$ Moreover, hormonal therapy in postmenopausal women had enhanced IGF-1 receptor expression. ${ }^{16}$ Estrogen reportedly has direct (i.e. estrogen receptors $\beta$ and $\alpha$ ) and indirect (i.e. GH/IGF-1 axis) effects on IGF- $1 .{ }^{4}$ However, how the LOF may modulate IGF-1 RNAm expression appears dependent on age (immature versus postmenopause) remains unanswered.

The IGF-1 is considered an important stimulator of skeletal muscle growth. The overexpression of IGF- 1 in skeletal muscle has induced hypertrophy in transgenic mice when compared with wild-type mice. ${ }^{13,25}$ However, our results show that the ovariectomy-increased IGF-1 mRNA did not change the CSA of muscle fibers ( $\mathbf{- F i g . ~ 2 A )}$ ). These results suggest that there is no clear relationship between increased IGF-1 mRNA and increased IGF-1 protein. Additionally, IGF-1 splice variants (IGF-1Ea, IGF-1Eb and IGF-1Ec) have distinct roles in muscle growth. ${ }^{26,27}$ Considering that our qPCR measured "mature" IGF-1, we cannot distinguish isoforms of the muscle IGF-1, we can only say that it increased by loss of ovarian function. Thus, a lack of data on specific IGF-1 splice variants and IGFBPs expression of the current study is possibly a limitation. Nevertheless, any possible effects that muscle IGF-1 and its isoforms may have had on muscle hypertrophy seem to be negligible in the context of loss of ovarian function.

The current study showed that rheumatoid arthritis model induces muscle atrophy ( $\boldsymbol{- F i g} . \mathbf{2 A}$ and Figure B) and increases IGF-1 mRNA in muscle atrophy (-Fig. 3A). These findings are similar to those described by other researchers. $^{10-12}$ Researchers have reported that increased muscle IGF-1 mRNA in muscle atrophy of arthritic rats has a relationship between the inflammatory response, induced by rheumatoid arthritis, ${ }^{10}$ and muscle regeneration. ${ }^{14}$ Considering IGF-1 is an important stimulator of skeletal muscle growth, upregulation of IGF-1 mRNA during the rheumatoid arthritis could be an attempt to mitigate the muscle atrophy. ${ }^{13,25}$ However, when we separated the groups in experimental conditions for comparison, we observed that CSA of 
muscle fiber was lower in RAOV ( - Fig. 2A-B), but there was no difference in muscle IGF-1 mRNA between RA and RAOV groups. These data suggest that a lower CSA of muscle fiber in arthritic rats with LOF is not associated to muscle IGF-1 mRNA response. Our findings converge with previous studies that have shown that the ability of estrogen and hormone replacement to maintain or augment muscle mass is regardless of IGF-1 responses. $4,5,18,28$

Myostatin inhibits expression of the myogenic regulatory factors, thus inhibiting proliferation and differentiation of skeletal muscle myoblasts. ${ }^{7,8}$ Myostatin has been associated with muscle wasting in different atrophy models. ${ }^{7,8,29}$ However, our study did not support increased myostatin mRNA in rheumatoid arthritis and ovariectomy models. Indeed, myostatin has not been associated with muscle wasting in rheumatoid arthritis ${ }^{30}$ or ovariectomy ${ }^{17}$ models. However, while Castillero et al. ${ }^{30}$ have not found increased myostatin mRNA in muscle after 15 days through administration of adjuvant injection, Ramírez et al. ${ }^{29}$ have found increased myostatin mRNA in muscle after two days of I-carrageenan injection. These two studies suggest that after induction of rheumatoid arthritis there is an early myostatin increase, which returns to basal levels after a few days. Thus, in the current study, the myostatin mRNA may have already peaked before the time of our muscle excision.

Increased proteolytic genes (i.e., E3 ubiquitin ligase) are indicative of protein degradation in the ubiquitin-proteasome system. ${ }^{9}$ The increased E3 ubiquitin ligase genes, such as atrogin-1 and MuRF-1, have been associated with muscle wasting in different atrophy models. ${ }^{10,29,31}$ However, in the current study, there was a substantial increase in atrogin-1 gene expression in the muscle atrophy of the arthritic rats, but not in MuRF-1 mRNA. The atrogin-1 and MuRF1 have a different role in the degradation of muscle proteins, ${ }^{32}$ thus these data imply that upstream factors of atrogin- 1 and MuRF-1 mRNA might be differently stimulated in rheumatoid arthritis.

Increased atrogin-1 and MuRF-1 have also been associated with LOF. ${ }^{5}$ Dieli-Conwright et $\mathrm{al}^{5}$ investigated proteolytic gene expression in postmenopausal women taking and not taking hormone replacement therapy and reported increased gene expression of atrogin-1 and MuRF-1 in postmenopausal women not taking hormone replacement therapy. Our data support previous findings that have suggested that estrogen act as anticatabolic agents based on higher gene expression levels of the atrogin-1 and MuRF-1 in lowered muscle of ovariectomized rats and postmenopausal women. ${ }^{4,5,28}$

The ability of estrogen to diminish systemic and muscle inflammatory factors is a potential protector against muscle damage. ${ }^{4}$ As the rheumatoid arthritis is an inflammatory disease, ${ }^{3}$ the absence of protective mechanism of estrogen (induced by ovariectomy) may have indirectly affected rheumatoid arthritis-induced $\mathrm{LSM}^{4}$ in the current study. This interaction between estrogen and inflammation and muscle may be supported by consistent reports of benefits of estrogen-mediated reductions in muscle inflammation and enhanced regeneration following disuse muscle atrophy in rodents. ${ }^{4}$ The chronic inflammation has been associated with LSM and increased activity of atrogin-1 and MuRF-1. ${ }^{33,34}$ Indeed, we observed a higher joint thickness on day 15 concomitantly with higher ubiquitin ligases atrogin-1 and MuRF-1 and lower relative muscle mass in RAOV group compared with RA group. As the joint thickness has been considered an indirect measure of inflammatory response in rheumatoid arthritis, ${ }^{10-12}$ our findings suggest that the RAOV group could have had an extended inflammatory response compared with RA group, inducing higher loss of skeletal muscle-related ubiquitin ligases atrogin-1 and MuRF-1.

In summary, LOF results in increased loss of skeletal muscle associated with ubiquitin ligases atrogin-1 and MuRF-1 in rheumatoid arthritis. These results suggest that a therapeutic approach targeting the maintenance of ovarian function can be effective in counteracting LSM in rheumatoid arthritis. Moreover, the knowledge of regulatory pathways of loss of ovarian function-induced LSM during rheumatoid arthritis, such as atrogin-1 and MuRF-1, may have identified new therapeutic targets. Therefore, future studies are required to evaluate whether these therapeutic approaches will be effective.

\section{Acknowledgment}

This investigation was supported by Fundação de Amparo à Pesquisa do Estado de Minas Gerais - FAPEMIG and by Coordenação de Aperfeiçoamento de Pessoal de Nível Superior - CAPES.

\section{References}

1 von Haehling S, Anker SD. Prevalence, incidence and clinical impact of cachexia: facts and numbers-update 2014. J Cachexia Sarcopenia Muscle 2014;5(4):261-263

2 Alamanos Y, Drosos AA. Epidemiology of adult rheumatoid arthritis. Autoimmun Rev 2005;4(3):130-136

3 Rall LC, Roubenoff R. Rheumatoid cachexia: metabolic abnormalities, mechanisms and interventions. Rheumatology (Oxford) 2004;43(10):1219-1223

4 Tiidus PM, Lowe DA, Brown M. Estrogen replacement and skeletal muscle: mechanisms and population health. J Appl Physiol (1985) 2013;115(5):569-578

5 Dieli-Conwright CM, Spektor TM, Rice JC, Sattler FR, Schroeder ET. Influence of hormone replacement therapy on eccentric exercise induced myogenic gene expression in postmenopausal women. J Appl Physiol (1985) 2009;107(5):1381-1388

6 Dieli-Conwright CM, Spektor TM, Rice JC, Sattler FR, Schroeder ET. Hormone therapy and maximal eccentric exercise alters myostatin-related gene expression in postmenopausal women. J Strength Cond Res 2012;26(5):1374-1382

7 McCroskery S, Thomas M, Maxwell L, Sharma M, Kambadur R. Myostatin negatively regulates satellite cell activation and selfrenewal. J Cell Biol 2003;162(6):1135-1147

8 McFarlane C, Plummer E, Thomas M, et al. Myostatin induces cachexia by activating the ubiquitin proteolytic system through an NF-kappaB-independent, FoxO1-dependent mechanism. J Cell Physiol 2006;209(2):501-514

9 Bodine SC, Latres E, Baumhueter S, et al. Identification of ubiquitin ligases required for skeletal muscle atrophy. Science 2001;294(5547):1704-1708

10 Castillero E, Martín AI, López-Menduiña M, Granado M, Villanúa MA, López-Calderón A. IGF-I system, atrogenes and myogenic 
regulatory factors in arthritis induced muscle wasting. Mol Cell Endocrinol 2009;309(1-2):8-16

11 López-Menduiña M, Martín AI, Castillero E, Villanúa MA, LópezCalderón A. Short-term growth hormone or IGF-I administration improves the IGF-IGFBP system in arthritic rats. Growth Horm IGF Res 2012;22(1):22-29

12 López-Menduiña M, Martín AI, Castillero E, Villanúa MA, LópezCalderón A. Systemic IGF-I administration attenuates the inhibitory effect of chronic arthritis on gastrocnemius mass and decreases atrogin-1 and IGFBP-3. Am J Physiol Regul Integr Comp Physiol 2010;299(2):R541-R551

13 Ye F, Mathur S, Liu M, et al. Overexpression of insulin-like growth factor- 1 attenuates skeletal muscle damage and accelerates muscle regeneration and functional recovery after disuse. Exp Physiol 2013;98(5):1038-1052

14 Tidball JG. Inflammatory processes in muscle injury and repair. Am J Physiol Regul Integr Comp Physiol 2005;288(2):R345-R353

15 Velders M, Schleipen B, Fritzemeier KH, Zierau O, Diel P. Selective estrogen receptor- $\beta$ activation stimulates skeletal muscle growth and regeneration. FASEB J 2012;26(5):1909-1920

16 Ahtiainen M, Pöllänen E, Ronkainen PH, et al. Age and estrogenbased hormone therapy affect systemic and local IL-6 and IGF-1 pathways in women. Age (Dordr) 2012;34(5):1249-1260

17 Tsai WJ, McCormick KM, Brazeau DA, Brazeau GA. Estrogen effects on skeletal muscle insulin-like growth factor 1 and myostatin in ovariectomized rats. Exp Biol Med (Maywood) 2007;232(10):1314-1325

18 Mangan G, Bombardier E, Mitchell AS, Quadrilatero J, Tiidus PM. Oestrogen-dependent satellite cell activation and proliferation following a running exercise occurs via the PI3K signalling pathway and not IGF-1. Acta Physiol (Oxf) 2014; 212(1):75-85

19 Khajuria DK, Razdan R, Mahapatra DR. Description of a new method of ovariectomy in female rats. Rev Bras Reumatol 2012; 52(3):462-470

20 Bär KJ, Schaible HG, Bräuer R, Halbhuber KJ, von Banchet GS. The proportion of TRPV1 protein-positive lumbar DRG neurones does not increase in the course of acute and chronic antigen-induced arthritis in the knee joint of the rat. Neurosci Lett 2004;361(1-3):172-175

21 Filippin LI, Teixeira VN, Viacava PR, Lora PS, Xavier LL, Xavier RM. Temporal development of muscle atrophy in murine model of arthritis is related to disease severity. J Cachexia Sarcopenia Muscle 2013;4(3):231-238

22 Aguiar AF, Vechetti-Júnior IJ, Alves de Souza RW, et al. Myogenin, MyoD and IGF-I regulate muscle mass but not fiber-type conver- sion during resistance training in rats. Int J Sports Med 2013; 34(4):293-301

23 Fisher JS, Kohrt WM, Brown M. Food restriction suppresses muscle growth and augments osteopenia in ovariectomized rats. J Appl Physiol (1985) 2000;88(1):265-271

24 Shinoda M, Latour MG, Lavoie JM. Effects of physical training on body composition and organ weights in ovariectomized and hyperestrogenic rats. Int J Obes Relat Metab Disord 2002;26(3): 335-343

25 Musarò A, McCullagh K, Paul A, et al. Localized Igf-1 transgene expression sustains hypertrophy and regeneration in senescent skeletal muscle. Nat Genet 2001;27(2):195-200

26 Engert JC, Berglund EB, Rosenthal N. Proliferation precedes differentiation in IGF-I-stimulated myogenesis. J Cell Biol 1996; 135(2):431-440

27 Philippou A, Papageorgiou E, Bogdanis G, et al. Expression of IGF-1 isoforms after exercise-induced muscle damage in humans: characterization of the MGF E peptide actions in vitro. In Vivo 2009;23(4):567-575

28 Dieli-Conwright CM, Spektor TM, Rice JC, Sattler FR, Schroeder ET. Hormone therapy attenuates exercise-induced skeletal muscle damage in postmenopausal women. J Appl Physiol (1985) 2009; 107(3):853-858

29 Ramírez C, Russo TL, Sandoval MC, et al. Joint inflammation alters gene and protein expression and leads to atrophy in the tibialis anterior muscle in rats. Am J Phys Med Rehabil 2011;90(11): 930-939

30 Castillero E, Nieto-Bona MP, Fernández-Galaz C, et al. Fenofibrate, a PPARalpha agonist, decreases atrogenes and myostatin expression and improves arthritis-induced skeletal muscle atrophy. Am J Physiol Endocrinol Metab 2011;300(5): E790-E799

31 Macedo AG, Krug AL, Herrera NA, Zago AS, Rush JW, Amaral SL. Low-intensity resistance training attenuates dexamethasone-induced atrophy in the flexor hallucis longus muscle. J Steroid Biochem Mol Biol 2014;143:357-364

32 Petroski MD, Deshaies RJ. Function and regulation of cullin-RING ubiquitin ligases. Nat Rev Mol Cell Biol 2005; 6(1):9-20

33 Sandri M. Signaling in muscle atrophy and hypertrophy. Physiology (Bethesda) 2008;23:160-170

34 Zoico E, Roubenoff $R$. The role of cytokines in regulating protein metabolism and muscle function. Nutr Rev 2002; 60(2):39-51 